\title{
Validation of the Publication of New Names and New Combinations Previously Effectively Published Outside the IJSB
}

\author{
List No. $15 \dagger$
}

The purpose of this announcement is to effect the valid publication of the following new names and new combinations under the procedure described previously (Int. J. Syst. Bacteriol. 27(3):iv, 1977). Authors and other individuals wishing to have new names and/or combinations included in future lists should send the pertinent reprint or a photocopy thereof to the IJSB for confirmation that all of the other requirements for valid publication have been met. It should be noted that the date of valid publication of these new names and combinations is the date of publication of this list, not the date of the original publication of the names and combinations. The authors of the new names and combinations are as given below, and these authors' names will be included in the author index of the present issue and in the volume author index in this issue of the IJSB.

(Inclusion of a name on these lists validates the name and thereby makes it available in bacteriological nomenclature. The inclusion of a name on this list is not to be construed as taxonomic acceptance of the taxon to which the name is applied. Indeed, some of these names may, in time, be shown to be synonyms, or the organism may be transferred to another genus, thus necessitating the creation of a new combination.)

\begin{tabular}{|c|c|c|c|}
\hline Name & Proposed as: & $\begin{array}{c}\text { Author(s) } \\
\text { (reference) }\end{array}$ & Nomenclatural type ${ }^{a}$ \\
\hline $\begin{array}{l}\text { Azospirillum amazonense } \\
\text { Aeromonas caviae } \\
\text { Alcaligenes denitrificans subsp. xylo- } \\
\text { soxydans (basonym: Achromobacter } \\
\text { xylosoxydans) }\end{array}$ & $\begin{array}{l}\text { New species } \\
\text { Revived name } \\
\text { New combination }\end{array}$ & $\begin{array}{l}\text { Magalhāes et al. (17) } \\
\text { Popoff (22) } \\
\text { (Yabuuchi and Yano) Kersters and De } \\
\text { Ley (120) }\end{array}$ & $\begin{array}{l}\text { ATCC } 35119(=\text { Am } 14(\mathrm{Y} 1))^{b} \\
\text { ATCC } 15468^{b} \\
\text { ATCC } 27061^{c}\end{array}$ \\
\hline Anaplasma caudatum & New species ${ }^{d}$ & Ristic and Kreier (25) & No culture isolated \\
\hline Anaplasma centrale & Revived name & Ristic and Kreier (25) & No culture isolated \\
\hline Branhamella (genus Branhamella) & New subgenus & Bøvre (3) & Moraxella (Branhamella) catarrhalise \\
\hline Clostridium magnum & New species & Schink (29) & DSM 2767 (= strain Wo Bd P1) \\
\hline Desulfovibrio baculatus & New species & Rozanova and Nazina (26) & INMI strain $\mathrm{X}$ \\
\hline $\begin{array}{l}\text { Ehrlichia sennetsu (basonym: Rickett- } \\
\text { sia sennetsu) }\end{array}$ & New combination & $\begin{array}{l}\text { (Misao and Kobayashi) Ristic and } \\
\text { Huxsoll (23) }\end{array}$ & No culture isolated \\
\hline Falcivibrio & New genus & Hammann et al. (9) & F. grandis $^{b}$ \\
\hline Falcivibrio grandis & New species & Hammann et al. (9) & DSM 2710 (= strain L23-1b) ${ }^{b}$ \\
\hline Falcivibrio vaginalis & New species & Hammann et al. (9) & DSM 2711 (= strain V125) \\
\hline Grahamella & Revived name & Ristic and Kreier (24) & G. talpae ${ }^{b}$ \\
\hline Grahamella peromysci & Revived name & Ristic and Kreier (24) & No culture isolated \\
\hline Grahamella talpae & Revived name & Ristic and Kreier (24) & No culture isolated \\
\hline Haemobartonella canis & Revived name & Kreier and Ristic (15) & No culture isolated \\
\hline Haemobartonella felis & Revived name & Kreier and Ristic (15) & No culture isolated \\
\hline Haemophilus paracuniculus & New species & Targowski and Targowski (30) & ATCC $29986^{f}$ \\
\hline Halobacteroides & New genus & Oren et al. (20) & H. halobius ${ }^{b}$ \\
\hline Halobacteroides halobius & New species & Oren et al. (20) & ATCC 35273 (= strain MD-1) ${ }^{b}$ \\
\hline $\begin{array}{l}\text { Klebsiella pneumoniae subsp. ozaenae } \\
\text { (basonym: Klebsiella ozaenae) }\end{array}$ & New combination & (Abel) Ørskov (21) & ATCC $11296^{\circ}$ \\
\hline $\begin{array}{l}\text { Klebsiella pneumoniae subsp. rhino- } \\
\text { scleromatis (basonym: Klebsiella } \\
\text { rhinoscleromatis) }\end{array}$ & New combination & (Trevisan) Ørskov (21) & ATCC $13884^{e}$ \\
\hline Legionella feeleii & New species & Herwaldt et al. (10) & ATCC 35072 (= strain WO-44C) ${ }^{b}$ \\
\hline Legionella sainthelensi & New species & Campbell et al. (5) & $\underset{4)^{b}}{\operatorname{ATCC} 35248 \text { (= strain Mt. St. Helens }}$ \\
\hline Mendosicutes & New division & Murray (19) & Class Archaeobacteria ${ }^{8}$ \\
\hline Methylococcaceae & New family & Whittenbury and Krieg (34) & Methylococcus ${ }^{b}$ \\
\hline Methylomonas & Revived name & Whittenbury and Krieg (34) & M. methanica ${ }^{b}$ \\
\hline Methylomonas methanica & Revived name & Whittenbury and Krieg (34) & NCIB $11130^{h}$ \\
\hline Moellerella & New genus & Hickman-Brenner et al. (11) & M. wisconsensis $^{b}$ \\
\hline Moellerella wisconsensis & New species & Hickman-Brenner et al. (11) & ATCC 35017 (= strain 2896-78) \\
\hline Moraxella & New subgenus & Bøvre (3) & Moraxella (Moraxella) lacunata ${ }^{e}$ \\
\hline $\begin{array}{l}\text { Moraxella cuniculi (basonym: Neis- } \\
\text { seria cuniculi) }\end{array}$ & New combination & (Berger) Bøvre and Hagen (4) & ATCC $14688^{e}$ \\
\hline Mycoplasma glycophilum & New species & Forrest and Bradbury (8) & $\begin{array}{l}\operatorname{ATCC} 35277 \text { (= strain } 486=\text { NCTC } \\
10194)^{b}\end{array}$ \\
\hline Natronobacterium & New genus & Tindall et al. (31) & N. gregoryib \\
\hline Natronobacterium gregoryi & New species & Tindall et al. (31) & Strain SP2 $\left(=\right.$ NCMB 2189) ${ }^{b}$ \\
\hline Natronobacterium magadii & New species & Tindall et al. (31) & Strain MS3 $(=\text { NCMB } 2190)^{b}$ \\
\hline Natronobacterium pharaonis & New species & Tindall et al. (31) & DSM 2160 \\
\hline Natronococcus & New genus & Tindall et al. (31) & N. occultus ${ }^{b}$ \\
\hline Natranococcus occultus & New species & Tindall et al. (31) & Strain SP4 $\left(=\right.$ NCMB 2192) ${ }^{b}$ \\
\hline $\begin{array}{l}\text { Oceanospirillum maris subsp. william- } \\
\text { sae }\end{array}$ & New subspecies & Linn and Krieg (16) & ATCC $29547^{b}$ \\
\hline
\end{tabular}




\begin{tabular}{|c|c|c|c|}
\hline Name & Proposed as: & $\begin{array}{l}\text { Author(s) } \\
\text { (reference) }\end{array}$ & Nomenclatural type " \\
\hline Pelobacter carbinolicus & New species & Schink (28) & Strain Gra Bd $1(=\text { DSM } 2380)^{b}$ \\
\hline Pelobacter propionicus & New species & Schink (28) & Strain Ott Bd $1\left(=\right.$ DSM 2379) ${ }^{b}$ \\
\hline Phyllobacterium & Revived name & Knösel (14) & P. myrsinacearum ${ }^{b}$ \\
\hline Phyllobacterium myrsinacearum & Revived name & Knösel (14) & Strain LMG $2 \mathrm{t} 2^{b}$ \\
\hline Phyllobacterium rubiacearum & Revived name & Knösel (14) & Strain LMG $1 \mathrm{t}^{h}$ \\
\hline Rickettsia montana & Revived name & Weiss and Moulder (33) & ATCC VR-611 ${ }^{b}$ \\
\hline Rickettsiella chironomi & Revived name & Weiss et al. (32) & No culture isolated \\
\hline Rickettsiella grylli & Revived name & Weiss et al. (32) & No culture isolated \\
\hline Spirochaeta aurantia subsp. stricta & New subspecies & Canale-Parola (6) & Strain $\mathrm{J}_{4} \mathrm{~T}^{b}$ \\
\hline $\begin{array}{l}\text { Streptococcus salivarius subsp. ther- } \\
\text { mophilus }\end{array}$ & New subspecies & (Orla-Jensen) Farrow and Collins (7) & NCDO $573^{e}$ \\
\hline Syntrophobacter & New genus & Boone and Bryant (2) & S. woliniit \\
\hline Syntrophobacter wolinii & New species & Boone and Bryant (2) & $\begin{array}{l}\text { Strain DB (maintained as a coculture } \\
\text { with Desulfovibrio sp. strain G-11; } \\
\text { coculture = DSM 2805) }\end{array}$ \\
\hline Tenericutes & New division & Murray (19) & Mollicutes \\
\hline Thermomonospora chromogena & Revived name ${ }^{d}$ & McCarthy and Cross (18) & Strain Agre no. $577(=\text { NCIB 10212 })^{b}$ \\
\hline Thermomonospora fusca & Revived name & McCarthy and Cross (18) & ATCC 27730 (strain $190 \mathrm{Th})^{b}$ \\
\hline Trichococcus & New genus & Scheff et al. (27) & T. flocculiformis \\
\hline Trichococcus flocculiformis & New species & Scheff et al. (27) & Strain Echt $\left(=\right.$ DSM 2094) ${ }^{b}$ \\
\hline Vibrio marinus & Revived name & Baumann et al. (1) & ATCC $15381^{b}$ \\
\hline
\end{tabular}

$\dagger$ Lists 1 through 14 were published in the Int. J. Syst. Bacteriol. 27:306, 1977; 29:79, 1979; 29:436, 1979; 30:601, 1980; 30:676, 1980; 31:215, 1981; 31:382, 1981; 32:266, 1982; 32:384, 1982; 33:438, 1983; 33:672, 1983; 33:896, 1983; 34:91, 1984; and 34:270, 1984.

a Abbreviations: ATCC, American Type Culture Collection, Rockville, Md.; DSM, Deutsche Sammlung von Mikroorganismen, Göttingen, Germany: INMI, Institute for Microbiology, USSR Academy of Sciences, Moscow, U.S.S.R.; NCDO, National Collection of Dairy Organisms, Reading, England; NCIB, National Collection of Industrial Bacteria, Aberdeen, Scotland; NCMB, National Collection of Marine Bacteria, Aberdeen, Scotland; NCTC, National Collection of Type Cultures, London, England.

${ }^{b}$ Type designated by the author(s).

Type designated by the author of the basonym.

¿ Proposed as a new combination; however, the basonym is not on the Approved Lists (1980) and has not been subsequently validly published; therefore, it does not have nomenclatural standing.

e Type previously established (Approved Lists of Bacterial Names, Int. J. Syst. Bacteriol. 30:225-420, 1980).

$f$ Type designated by subsequent authors (13).

${ }^{8}$ Type by monotypy.

${ }^{h}$ Proposed as the neotype, but here regarded as the type.

\section{LITERATURE CITED}

1. Baumann, P., A. L. Furniss, and J. V. Lee. 1984. Genus Vibrio, p. 518-538. In N. R. Krieg and J. G. Holt (ed.), Bergey's manual of systematic bacteriology, vol. 1. The Williams \& Wilkins Co., Baltimore.

2. Boone, D. R., and M. P. Bryant. 1980. Propionate-degrading bacterium, Syntrophobacter wolinii sp. nov. gen. nov., from methanogenic ecosystems. Appl. Environ. Microbiol. 40:626632 .

3. Bøvre, K. 1979. Proposal to divide the genus Moraxella Lwoff 1939 emend. Henriksen and Bøvre 1968 into two subgenerasubgenus Moraxella (Lwoff 1939) Bøvre 1979 and subgenus Branhamella (Catlin 1970) Bøvre 1979. Int. J. Syst. Bacteriol. 29:403-406.

4. Bøvre, K., and N. Hagen. 1981. The family Neisseriaceae: rodshaped species of the genera Moraxella, Acinetobacter, Kingella, and Neisseria, and the Branhamella group of cocci, p. 1506-1529. In M. P. Starr, H. Stolp, H. G. Trüper, A. Balows, and H. G. Schlegel (ed.), The prokaryotes: a handbook on habitats, isolation, and identification of bacteria. SpringerVerlag, Berlin.

5. Campbell, J., W. F. Bibb, M. A. Lambert, S. Eng, A. G. Steigerwalt, J. Allard, C. W. Moss, and D. J. Brenner. 1984 Legionella sainthelensi; a new species of Legionella isolated from water near Mt. St. Helens. Appl. Environ. Microbiol. 27:369-373.

6. Canale-Parola, E. 1984. Genus Spirochaeta, p. 39-46. In N. R. Krieg and J. G. Holt (ed.), Bergey's manual of systematic bacteriology, vol. 1. The Williams \& Wilkins Co., Baltimore.

7. Farrow, J. A. E., and M. D. Collins. 1984. DNA base composition, DNA-DNA homology and long-chain fatty acid studies on Streptococcus thermophilus and Streptococcus salivarius. J. Gen. Microbiol. 130:357-362.

8. Forrest, M., and J. M. Bradbury. 1984. Mycoplasma glycophilum, a new species of avian origin. J. Gen. Microbiol, 130:597-
603.

9. Hammann, R., A. Kronibus, A. Viebahn, and H. Brandis. 1984. Falcivibrio grandis gen. nov. sp. nov., and Falcivibrio vaginalis gen. nov. sp. nov., a new genus and species to accommodate anaerobic motile curved rods formerly described as "Vibrio mulieris" (Prévot 1940) Breed et al. 1948. Syst. Appl. Microbiol. 5:81-96.

10. Herwaldt, L. A., et al. 1984. A new Legionella species, Legionella feeleii species nova, causes Pontiac fever in an automobile plant. Ann. Int. Med. 100:333-338.

11. Hickman-Brenner, F. W., G. P. Huntley-Carter, Y. Saitoh, A. G. Steigerwalt, J. J. Farmer III, and D. J. Brenner. 1984. Moellerella wisconsensis, a new genus and species of Enterobacteriaceae found in human stool specimens. J. Clin. Microbiol. $19: 460-463$.

12. Kersters, K., and J. De Ley. 1984. Genus Alcaligenes, p. 361373. In N. R. Krieg and J. G. Holt (ed.), Bergey's manual of systematic bacteriology, vol. 1. The Williams \& Wilkins Co., Baltimore.

13. Kilian, M., and E. L. Biberstein. 1984. Genus Haemophilus, p. 558-569. In N. R. Krieg and J. G. Holt (ed.), Bergey's manual of systematic bacteriology, vol. 1. The Williams \& Wilkins Co., Baltimore.

14. Knösel, D. H. 1984. Genus Phyllobacterium, p. 254-256. In N. R. Krieg and J. G. Holt (ed.), Bergey's manual of systematic bacteriology, vol. 1. The Williams \& Wilkins Co., Baltimore.

15. Kreier, J. P., and M. Ristic. 1963. Anaplasmosis. XII. The growth and survival in deer and sheep of the parasites present in the blood of calves infected with the Oregon strain of Anaplasma marginale. Am. J. Vet. Res, 24:697-702.

16. Linn, D. M., and N. R. Krieg. 1978. Occurrence of two organisms in cultures of the type strain of Spirillum lunatum: proposal for rejection of the name Spirillum lunatum and characterization of Oceanospirillum maris subsp. williamsae and an unclassified vibrioid bacterium. Int. J. Syst. Bacteriol. 28:132-138. 
17. Magalhães, F. M., J. I. Baldani, S. M. Souto, J. R. Kuykendall, and J. Döbereiner. 1983. A new acid-tolerant Azospirillum species. An. Acad. Brasil. Ciênc. 55:417-430.

18. McCarthy, A. J., and T. Cross. 1984. A taxonomic study of Thermomonospora and other monosporic actinomycetes. J. Gen. Microbiol. 130:5-25.

19. Murray, R. G. E. 1984. The higher taxa, or, a place for everything . . . ?, In N. R. Krieg and J. G. Holt (ed.), Bergey's manual of systematic bacteriology, vol. 1. The Williams \& Wilkins Co., Baltimore, p. 31-34.

20. Oren, A., W. G. Weisburg, M. Kessel, and C. R. Woese. 1984. Halobacteroides halobius gen. nov., sp. nov., a moderately halophilic anaerobic bacterium from the bottom sediments of the Dead Sea. Syst. Appl. Microbiol. 5:58-69.

21. Ørskov, I. 1984. Genus Klebsiella, p. 461-465. In N. R. Krieg and J. G. Holt (ed.), Bergey's manual of systematic bacteriology, vol. 1. The Williams \& Wilkins Co., Baltimore.

22. Popoff, M. 1984. Genus Aeromonas, p. 545-548. In N. R. Krieg and J. G. Holt (ed.), Bergey's manual of systematic bacteriology, vol. 1. The Williams \& Wilkins Co., Baltimore.

23. Ristic, M., and D. L. Huxsoll. 1984. Genus Ehrlichia, p. 704709. In N. R. Krieg and J. G. Holt (ed.), Bergey's manual of systematic bacteriology, vol. 1. The Williams \& Wilkins Co., Baltimore

24. Ristic, M., and J. P. Kreier. 1984. Genus Grahamella, p. 718 719. In N. R. Krieg and J. G. Holt (ed.), Bergey's manual of systematic bacteriology, vol. 1. The Williams \& Wilkins Co., Baltimore.

25. Ristic, M., and J. P. Kreier. 1984. Genus Anaplasma, p. 720 722. In N. R. Krieg and J. G. Holt (ed.), Bergey's manual of systematic bacteriology, vol. 1. The Williams \& Wilkins Co., Baltimore.
26. Rozanova, E. P., and T. N. Nazina. 1976. A mesophilic, sulfatereducing, rod-shaped nonspore-forming bacterium. Mikrobiologiya 45:825-830.

27. Scheff, G., O. Salcher, and F. Lingens. 1984. Trichococcus flocculiformis gen. nov. sp. nov. A new gram-positive filamentous bacterium isolated from bulking sludge. Appl. Microbiol. Biotechnol. 19:114-119.

28. Schink, B. 1984. Fermentation of 2,3-butanediol by Pelobacter carbinolicus sp. nov. and Pelobacter propionicus $\mathrm{sp}$. nov., and evidence for propionate formation from $\mathrm{C}_{2}$ compounds. Arch. Microbiol. 137:33-41.

29. Schink, B. 1984. Clostridium magnum sp. nov., a non-autotrophic homoacetogenic bacterium. Arch. Microbiol. 137:250-255.

30. Targowski, S., and H. Targowski. 1979. Characterization of a Haemophilus paracuniculus isolated from gastrointestinal tracts of rabbits with mucoid enteritis. J. Clin. Microbiol. 9:33-37.

31. Tindall, B. J., H. N. M. Ross, and W. D. Grant. 1984. Natronobacterium gen. nov, and Natronococcus gen. nov., two new genera of haloalkaliphilic archaebacteria. Syst. Appl. Microbiol. 5:41-57.

32. Weiss, E., G. A. Dasch, and K.-P. Chang. 1984. Genus Rickettsiella, p. 713-717. In N. R. Krieg and J. G. Holt (ed.), Bergey's manual of systematic bacteriology, vol. 1. The Williams \& Wilkins Co., Baltimore.

33. Weiss, E., and J. W. Moulder. 1984. Genus Rickettsia, p. 688698. In N. R. Krieg and J. G. Holt (ed.), Bergey's manual of systematic bacteriology, vol. 1. The Williams \& Wilkins Co., Baltimore.

34. Whittenbury, R., and N. R. Krieg. 1984. Family Methylococcaceae, p. 256-261. In N. R. Krieg and J. G. Holt (ed.), Bergey's manual of systematic bacteriology, vol. 1. The Williams \& Wilkins Co., Baltimore. 